\title{
BASIC PRINCIPLES OF ELECTRICAL NETWORK RELIABILITY OPTIMIZATION IN LIBERALISED ELECTRICITY MARKET
}

\author{
I. Oleinikova, Z. Krishans, A. Mutule \\ Institute of Physical Energetics, \\ Aizkraukles iela 21, Riga, LV-1006, LATVIA
}

\begin{abstract}
The authors propose to select long-term solutions to the reliability problems of electrical networks in the stage of development planning. The guide lines or basic principles of such optimization are: 1) its dynamical nature; 2) development sustainability; 3) integrated solution of the problems of network development and electricity supply reliability; 4) consideration of information uncertainty; 5) concurrent consideration of the network and generation development problems; 6) application of specialized information technologies; 7) definition of requirements for independent electricity producers. In the article, the major aspects of liberalized electricity market, its functions and tasks are reviewed, with emphasis placed on the optimization of electrical network development as a significant component of sustainable management of power systems.
\end{abstract}

\section{INTRODUCTION}

The electricity market in Latvia is regulated by the Law on Electricity Market adopted on May 5, 2005 (further in the text the Law). The Law regulates the operation of electricity market branches - including transmission and distribution networks - and the functions of traders and providers of services required for electricity trading. It also establishes the frames of competence for the Ministry of Economics and Public Services Regulatory Body [1].

In accordance with the Law, every electricity market participant reserves the right to use transmission and distribution networks for electricity transportation in compliance with the system service rates (tariffs). The consumer connected to a distribution network has the right to change the supplier by forwarding at least three months before a notice to him and to the system operator who is in administrative charge of the network connections.

The Regulations adopted by the Cabinet of Ministry on electricity trading and consumption determine the procedure by which electricity is supplied/not supplied to the consumer, the rights and obligations of the electricity traders, system operators and consumers in the sphere of electricity supply and use as well as the accounting procedure for the services provided. The Regulations define the procedure of a trader's shift or rotation. Annual electricity tariff in Latvia for relevant electricity users consists of the following components:

- electricity price;

- network tariff;

- component of support provided by domestic electricity producers. 
Since 2008, the amendments to the Law have been adopted which envisage the obligatory involvement in the liberalized electricity market of electricity users the enterprises with 50 and more employees or those with turnover per year not less than seven million Latvian lats (LVL).

The transmission network operator is liable for administration of a market participant's electricity balance for the users connected to a transmission network, whereas the distribution network operator deals with the users connected to a distribution network.

All market partners/participants have the right to use transmission and distribution lines for electricity transportation.

Since 2007 the electricity market in Latvia has been $100 \%$ opened, and all Latvian enterprises are entitled to make a free choice of the electricity supplier.

\section{RELIABILITY OF ELECTRICITY SUPPLY UNDER THE CONDITIONS OF LIBERALIZED ELECTRICITY MARKET}

Electricity may be considered as „current commodity”, whose particular characteristic is a restricted possibility for its storage and transportation. These time and space restrictions are basic conditions (in comparison with other commodities) for electricity price formation [2].

In the European Union the process of electricity market liberalization is going very fast (see Table 1). Now the market is fully liberalized in Austria, Finland, Germany, Norway, Sweden and Great Britain; it is partly liberalized in Denmark (90\%), Spain (54\%), Luxemburg (40\%), Belgium (35\%), Italy (35\%), Netherlands (33\%), France (30\%), Greece (30\%), Ireland (30\%), and Portugal (30\%).

The major aspect at implementation of liberalized electricity market is the opportunity to slow down the rise in annual electricity tariffs. The question as to the influence of competition on the decrease in electricity tariffs in the states where the electricity market exists is answered in the reports of the European Commission, where the electricity prices are listed for the period of 1996 up to 2004: indeed, owing to the implementation of liberalized electricity market the prices have decreased in many countries but not everywhere.

Adoption of liberalized electricity market is characterized by unbundling of transmission and distribution networks from generation, thus providing the buyer (consumer) with opportunity to make a free choice of the electricity trader (generator). Service utilities (distribution or transmission networks) are affected by increasing prices, being forced to reduce both the investments and the operation expenditures. Typical activities comprise: investment reduction, constraints in operation and maintenance, and considerable staff reduction. All these activities affect negatively the quality of the rendered services and the electricity supply reliability. This aspect has acquired a particular significance since the attention of society has been drawn to events in Oakland (New Zealand) in 2000, the wind storms in 1999/2000 in Europe, the energy crises in California (USA) and in Europe in 2003, the black-outs in USA in 2003 and in Russia in 2005. During the latest time, blackouts have become the cause for the liberalized electricity market priority in relation to the electricity supply reliability. Gradually, year-after-year, the electricity business has put aside the electricity reliability aspect, as businessmen's attitude was plain - to do nothing until something happens. 
All over the world, in a market liberalization process when the competitiveness is promoted, the aspect of reliability remains only a second target, which means high probability of emergencies. As far as the power systems are not anxious any more about the maximum reliability guarantees, the preconditions arise for emergency situations when the opposite interests are confronted, since businessmen are tending to acquire the maximum profit whereas the system operators - to maintain reliable and secure power supply. Such a situation exists both in Latvia and in the neighbouring countries - Lithuania and Estonia. Power systems of all these countries are interconnected through electrical cross-sections of transmission lines, which are limited in the allowable maximum power in the normal modes and maintenance schemes. The businessmen who are dealing with market electricity transactions are interested in the business efficiency promotion, while the operators of transmission networks - in the power supply reliability and security. The more rigid demands to the power supply reliability, the more restrictions on the liberalized electricity market. In such situations diversified solutions are sought for, and one of these is construction of new transmission lines with more capacious throughput power capacity in the cross-sections that could be overloaded under the conditions of liberalized electricity market; another alternative is construction of new generating sources in power-deficient regions.

\section{STRUCTURE, FUNCTIONS AND TASKS \\ OF LIBERALIZED ELECTRICITY MARKET}

The notion of liberalized electricity market is very intricate. Impossibility to store commodity (electricity) segregates the electricity market from financial markets and other commodity markets as the price formation mechanism is based on the balance between the demand and the production (generation) at each time instant. Theoretically, the electricity price exists each second, however in fact the market is based on the price per hour $(\mathrm{kWh})$. In order to move from the monopolized electricity market to a liberalized electricity market a number of problems should be solved [1]. Fig. 1.

The structural principles of liberalized electricity market are presented in

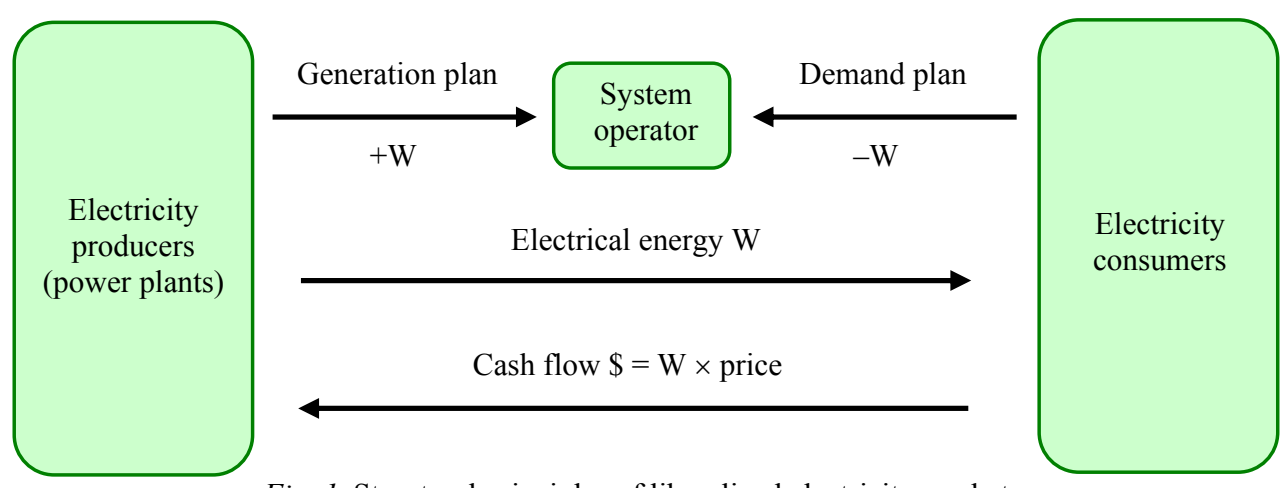

Fig. 1. Structural principles of liberalized electricity market.

In liberalized electricity market different products are purchased and sold: energy, power, reserves, reactive power/voltage maintenance, cold start-up, the 
regulation capacities (such as load shedding, energy quality, emergency clearance, etc.). Here:

energy - is a commodity that is delivered to the consumer as the end product (measured in $\mathrm{kWh}$ );

power $\quad-$ is what is generated each second $(\mathrm{kW})$; the power generated in an hour is called electric energy;

reserves $\quad-$ is the regulation range of power generating equipment intended to match consumption (demand) with generation (offer) each hour;

reactive power/voltage maintenance - is the technical part of electricity market whose task is to provide electricity supply to consumers with the least losses for the system;

cold start-up - is the power which due to increase in demand may be delivered after a definite time;

regulation capacities - market functioning elements .

Suppliers obtain profit from selling the optimal mix of mentioned products ("optimal mix selling").

The problems are caused by uncertain external conditions. Uncertainties are classified into physical, financial and regulatory (see Table 1, [2]).

Uncertainties classification

Table 1

\begin{tabular}{|l|l|l|}
\hline \multicolumn{1}{|c|}{ Physical uncertainties } & \multicolumn{1}{|c|}{ Financial uncertainties } & \multicolumn{1}{|c|}{ Regulatory uncertainties } \\
\hline Load forecast, & Interest rates, & Changeable Law, \\
Weather conditions, & Credits, & Political pressure, \\
Generators tripping, & Competitiveness, & $\begin{array}{l}\text { Influence exerted by interests } \\
\text { group. }\end{array}$ \\
$\begin{array}{c}\text { Other equipment faults, } \\
\text { Other errors (human persons, } \\
\text { dispatcher and relay } \\
\text { malfunction), } \\
\begin{array}{c}\text { Equipment operation } \\
\text { availability, }\end{array}\end{array}$ & Cash flow. \\
Scheduling uncertainties. & & \\
\hline
\end{tabular}

At determination of expenditures and prices the interests of supplier and user should be taken into consideration (see Table 2, [2]).

Factors that determine product price

\begin{tabular}{|l|l|}
\hline \multicolumn{1}{|c|}{ Supplier's interests } & \multicolumn{1}{c|}{ Consumers' (users') interests } \\
\hline Supplier's product expenditures are & Payments of consumers (users) are determined \\
determined by: & by: \\
Fuel costs / contracts, & Local regulatory regime, \\
Operation and maintenance, & Options selected by the user, \\
Capital costs, & Selection of user control; \\
Extra costs (network, emergency, losses, & Load supply to points: \\
independent system operators) & Expenditures - mainly capital costs - are related \\
Physical assets management, & to distribution assets, regulation and operation, \\
External conditions and uncertainties. & The prices are determined by market or \\
Market determines the supplier prices. & Regulators \\
\hline
\end{tabular}


During any restructuring transition period from the regulated market to a free or liberalized market the relationships between the supplier and the user are not symmetrical. Therefore formation of a fully competitive market is a hard problem.

Risks arising under the conditions of non-regulated (liberalized) market are managed by suppliers and users. This could be characterized as follows.

- Suppliers are subject to all risks formulated above.

- Users may be protected in a transition period but not all the time.

- „Regulator" may help or slow down the market effect (i.e. to enhance or mitigate suppliers' and users' risks).

- The major conclusion: "salvation" resulting from competition may be balanced with higher prices to cover the supplemental costs caused by risk.

The reviewed considerations determine the general structure of liberalized market (see Fig. 2).

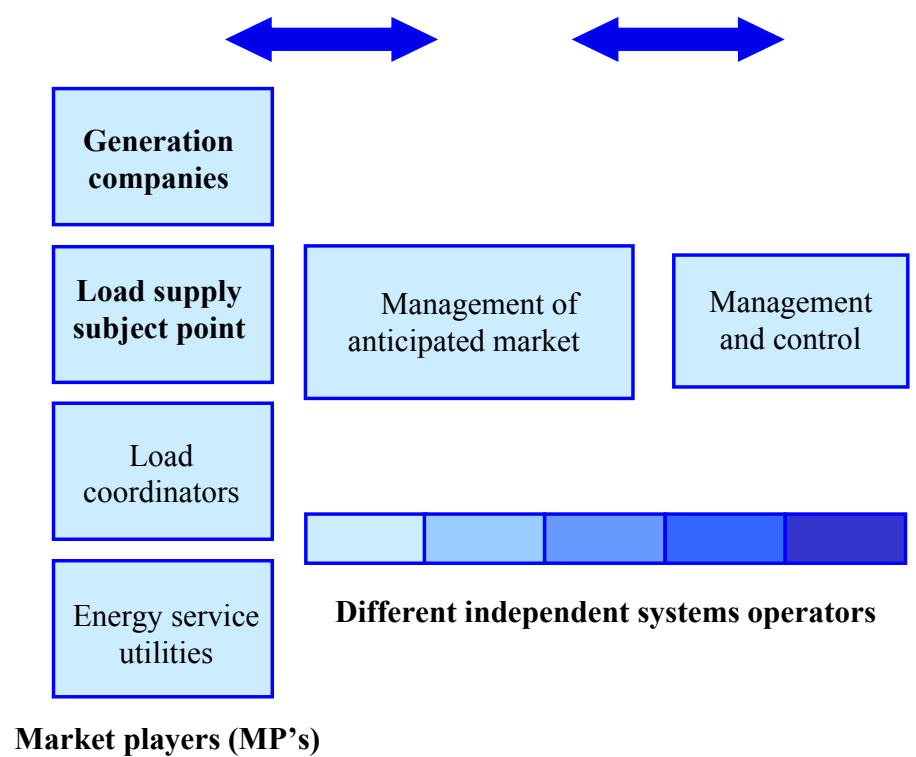

Fig. 2. General structure of liberalized market

On a liberalized electricity market the process of consumption (demand) and power generation planning should be flexible taking into consideration interests of all participants. Consumption schedules should be worked out in such a way that the load (demand) coordinator corrects the existing on-line operation to the least extent.

\section{THE BASIC PRINCIPLES OF ELECTRICAL NETWORK RELIABILITY OPTIMIZATION UNDER LIBERALIZED ELECTRICITY MARKET}

The basic theses of the electrical network reliability optimization concept have been elaborated in line with the main problems of liberalized electricity market, its functions and components as well as with the analytic results of the network sustainability aspect. The theses present summary results obtained in the framework of the scientific research project „The Network Reliability Optimization 
under Liberalized Electricity Market" (guided by Assoc. Professor, Dr. sc. ing. Irina Oleinikova (2004-2008)). The project involves the methods of electrical power supply reliability evaluation and optimization, both for transmission and distribution networks. The elaborated methods have already been used in the process of planning the Latvian power system's development. The results are presented in many publications and reported in proceedings of several international conferences [4-17].

The first - and the most important - implication of the analysis is that under new conditions the network development and reliability planning, along with its optimization issues, becomes increasingly important. The network development should be planned hand-in-hand with its reliability. The existing methods should also be essentially reviewed and supplemented, and only then the planning of network development and power supply reliability may give the desirable results. We have worked out seven basic theses taking the totality of long-term experience of the network development planning. The theses can be recommended when working out new methods for the development optimization. These are as follows.

\section{Optimization should be dynamic:}

a) regular;

b) flexible and accessible for adjustment/correction.

As a rule, the network development is a continuous process, which may not be replaced by $1-3$ development horizons. Such a model, as our researchers have proved, distorts the feasibility comparison of the variants. Under the conditions of liberalized electricity market only the model of a multi-step development process should be applied. The economic analysis in compliance with the method should be performed on an object's economic life cycle (in electrical networks - 20-25 years). The objective function should be calculated for the whole estimation period $T$. Under the conditions of information uncertainty the ultimate decision should be taken for a not very far perspective $-3-5$ years. We will nominate this time interval the decision making period $t_{d}<T[8]$.

Since the information on the development during the calculation period is uncertain, the made decisions should be regularly specified. The development planning should proceed gradually [8]:

- observing external information revision;

- using the input information and decisions made in the previous stages on the specific objects;

- using updated information on the previous development of the system.

\section{Optimization should consider the sustainability}

of an electric power system in a far perspective in order to estimate potential consequences of the decision making.

In fact, if the aspect of sustainable network management is not taken into consideration, the estimation period is $20-25$ years (precisely modelled with 10 development steps); at the same time, observance of the mentioned aspect allows for estimation of a 50 -year period ( 20 development steps). 


\section{For optimization of the electrical network reliability level it should be taken into consideration that additional investments are required for reliability improvement, therefore relevant reliability estimation criteria are to be applied.}

Electric power supply reliability is a significant component of the electric energy quality, which affects the liberalized electricity market. The main reliability criteria are: the number of faults, the duration of power supply interruptions, the non-delivered electricity and the related expenditures associated with non-delivered electricity. The reliability criteria of the electric power supply are formed of those for 1) power plants, 2) transmission network, and 3) distribution network (in the general case the medium- and low-voltage networks).

\section{The target of electric power supply optimization under the conditions of liberalized electricity market is demand formulation to independent energy producers.}

The main problem at reliability estimation is that the maintenance of a definite quality of power supply entails costs for the system owner; at the same time, low quality means expenditures for the consumer. Power supply quality, along with the price, is the most peculiar characteristic of electric energy, especially as concerns industrial consumers.

From the viewpoint of consumers it would be preferable to form a structure where the consumer may select an acceptable quality level of power supply and respective costs. For example, in [3] it is proposed for the consumer to select the respective reliability level paying the charge for connection and service as well as the insurance fee for additional reliability. In Fig. 3 the general principles of this approach are presented.

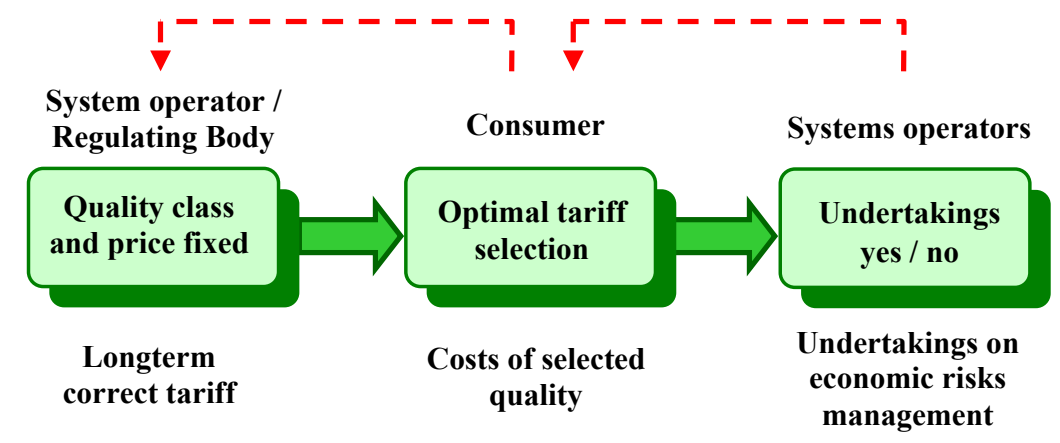

Fig. 3. Power supply quality structure focused on the consumer

The methods of reliability estimation are structured into two groups: 1) short-term and 2) long-term ones.

The first group is applied in the power system and network operative management, while the second - for the development planning (network development optimization included).

The reliability criteria recommended for the development optimization are: 1) non-delivered energy; 2) costs of non-delivery; 3) duration of power supply interruption. 
The reliability criteria should be calculated for: 1) the lines (analyzing all trippings of the lines in sequence and assuming that the overloaded lines must be disconnected), 2) the equipment of substations and distribution switchgears.

\section{For optimization, the following information uncertainty aspects should be observed:} tainties.

a) physical uncertainties; b) financial uncertainties; c) regulatory uncer-

The recommended procedure for selecting options under uncertainty conditions is: 1) a set of information is selected which should represent the diapason of credibility; then the $i$-th set is named forecast $l ; 2$ ) the option estimation criterion is selected; 3 ) comparable options are selected; 4) the optimal option is selected.

As many researchers demonstrate, to estimate the options under uncertainty conditions it is sufficient to apply a comparatively small information set that would represent the credibility interval. This is due to the following: 1) the objective function curve in the optimum range is very flat; 2) system parameters change discretely.

The most suitable criterion for the optimization task of electrical network development is the minimum/maximum risk [9].

In the risk analysis the notion of adaptation is important.

Differentiation of the decision making and estimation period $\left(t_{d}<T\right)$ calls for radical changes in definition of the development option, which should now be characterized only by realized undertakings (measures) during the decision making period.

The undertakings realized beyond the limits of the decision making period are obtained in the risk analysis by adaptation (dynamic optimization)).

\section{For optimization, the networks and generation should be considered in parallel.}

For modelling the energy source, the network model should be supplemented with generator units and links of electric power plants [8].

Applying these links, we can also model the energy saving technologies, the liberalized electricity market, and the electricity import from neighbouring power systems. At solving concurrently the tasks of network and generation system development tasks the annual loads and generation curves can be coordinated in the model. It is advisable to consider 13 operating regimes (each month corresponding to one operating regime): 1) January, 2) February, ..., 12) December, and 13) postemergency. Such a model allows for analyzing the systems with hydro- and wind power plants, and cogeneration plants, as the output of power plants depends on meteorological conditions.

In the process of parallel optimization of networks and generation systems the number and structure of the operating energy sources vary depending on the development plan (step) as well on the operating conditions and tariffs. In order to perform comparison of different options these should be considered with respect to the optimal load distribution among the energy sources. Such optimization calculation should be performed for all options in all development steps and modes. 


\section{For optimization, specialized information technologies should be applied.}

Application of information technologies ensures the opportunity:

- to raise the efficiency of planning by standardizing its processes and applied software, and by automating the software application process;

- to reduce the operation and maintenance costs of information technology systems, substituting highly integrated and upgraded software sets for multiple software [9].

As a result of optimization, the demand to independent energy producers should be formulated.

\section{SUMMARY}

The forecast for the liberalized electricity market is that it will be characterized by ongoing investment cycles for electric power plants, during which such a market may experience periods either of generation power surplus or of its deficit. It would be wrong to think that the electricity market liberalization is a single event or realized undertaking - in reality it is a continuous process that calls for ongoing market improvement.

\section{CONCLUSIONS}

These are as follows.

1. The significance of network development optimization under the conditions of liberalized electricity market is ever increasing.

2. Under the conditions of liberalized electricity market it is necessary to use new advanced methods for planning the electrical network development.

3. The primary principles formulated in the paper are recommended as the basis for working out new methods of network development optimization.

4. The basic theses formulated in general relate to transmission networks and power plant systems as well as to distribution networks and scattered power plants.

\section{REFERENCES}

1. AS "Latvenergo" homepage www.latvenergo.lv.

2. Ahmad, M., Debs, A., Gdob, R., \& Hansen, C. (2003). Electricity Market Simulation \& Price Forecasting. USA, DSI.

3. Kochs, H.-D. (1984). Zuverlassigkeit Elektrischer Anlagen. Berlin, New York, Tokio: Springer Verlag.

4. Krishans, Z., Oleinikova, I., \& Kutjuns, A. (2005). Reliability Problems in Baltic Countries Power Networks under Liberalized Electricity Market Conditions.

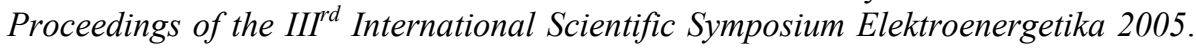
Stará Lesná (Slovak Republic). CD 9 pp.

5. Krishans, Z., Oleinikova, I., Mutule, A., \& Runcs, J. (2005). Method for Transmission Networks and Generation System Development Optimisation. Zinātnisko rakstu krājums Energéetika un elektrotehnika, sērija 4, sējums 14, Rīga, RTU, 116122. 
6. Krishans, Z., Kutjuns, A., \& Oleinikova, I. (2005). Transmission Network Reliability Calculation with Conventional Load Non-Supply Criterion. Electro-Tech 2005. Budapest, Hungary. $1^{\text {st }}$ International Scientific Conference publications, Budapest Polytechnic Institute (on CD 9 pp.).

7. Krishans, Z., Kutjuns, A., \& Oleinikova, I. (2005). Transmission Network Reliability Calculation with Conventional Load Non-Supply Criterion. Международная научно-техническая конференция Перенапряжения и надежность эксплуатации электрооборудования, ред. Н.Н.Тиходеев, выпуск 4, Материалы международной научно-технической конференции. Будапешт, Санкт-Петербург, 192-200.

8. Krishans, Z., Mutule, A., \& Oleinikova, I. (2006). Structure of Optimisation Models System for Planning of Power System under Market Conditions. Electric Power Engineering (EPE) 2006. Brno (Czech Republic). Proceedings of the $7^{\text {th }}$ International Scientific Conference, Brno University of Technology, 19-23.

9. Krishans, Z., Kutjuns, A., \& Oleinikova, I. (2006). Baltic Countries Power Networks Reliability Problems under Market Conditions and Methods of Reliability Improvement. Proceedings of the $7^{\text {th }}$ International Scientific Conference Electric Power Engineering 2006. Brno, Czech Republic, 59-63.

10. Krishans, Z., Oleinikova, I., Mutule, A., \& Kutjuns, A. (2006). Optimization Method of Power System Development under Uncertainty. $9^{\text {th }}$ International Conference on Probabilistic Methods Applied to Power Systems. KTH, Stockholm, Sweden. Symposium Proceedings (on CD 5 pp.).

11. Krishans, Z., Oleinikova, I., Mutule, A., \& Runčs, J. (2006). Method for Power System Modernization Asset Management Optimization under Liberalization. Liberalization and Modernization of Power Systems: Risk Assessment and Optimization for Asset Management, IEEE Power Engineering Society, Russia, Irkutsk. $3^{\text {rd }}$ International Workshop Proceedings, 36-41.

12. Krishans, Z., Oleinikova, I., Mutule, A., \& Runčs, J. (2006). Dynamic Simulation Method for Transmission and Distribution Planning. WSEAS TRANSACTIONS on SYSTEMS and CONTROL, Issue 2, Volume 1, 155-160.

13. Krishans, Z., Oleinikova, I., Mutule, A., Runčs, J., \& Kalpiņa, A. (2006). Vidsprieguma sadales tīkla drošuma tehniski ekonomiskās analīzes imitācijas datorprogramma Latv. J. Phys. Tech. Sci 6 35-47.

14. Krishans, Z., Oleinikova, I., Mutule, A., \& Runcs, J. (2006). Medium voltage Urban Distribution Networks Power Supply Reliability estimation. Proceedings of the IV ${ }^{\text {th }}$ International Scientific Symposium Elektroenergetika 2007. Stará Lesná, Slovak Republic. Symposium Proceedings (on CD).

15. Krishans, Z., Oleinikova, I., \& Mutule, A., (2007). Planning for Urban Medium Voltage Network. CHALLENGES IN POWER, HIGH VOLTAGES and MACHINES, Published by WSEAS Press, 180-185.

16. Kutjuns, A., \& Krishans, Z. (2007). Method of Transmission Power Networks Reliability Estimation. CHALLENGES IN POWER, HIGH VOLTAGES and MACHINES, Published by WSEAS Press, 198-202.

17. Merkurjevs, Y., Krishans, Z., Oleinikova, I., \& Mutule, A. (2008). Application of Probabilistic Method for Switchyard Types Selection in Transmission Networks. $10^{\text {th }}$ International Conference on Probabilistic Methods Applied to Power Systems. Rincón, Puerto Rico. Symposium Proceedings (on CD 5 pp.). 


\section{ELEKTRISKO TĪKLU DROŠUMA OPTIMIZĀCIJAS PAMATPRINCIPI BRĪVĀ ELEKTROENERĢIJAS TIRGŪ}

I. Oḷeiņikova, Z. Krišāns, A. Mutule

Kopsavilkums

Rakstā piedāvāts elektrisko tīklu drošuma problēmu ilglaicīgos risinājumus izvēlēties kopējā elektrisko tīklu attīstības plānošanas procesā. Šādas attīstība optimizācijas pamatprincipi (īpašības) ir: 1) dinamiskums; 2) attīstības ilgtspējas nodrošināšana; 3) tīkla attīstības un apgādes drošuma problēmu kompleksa risināšana; 4) informācijas nenoteiktības ievērošana; 5) tīkla un generācijas attīstības problēmu vienlaicīgs apskats; 6) specializētu informācijas tehnolog̣iju izmantošana; 7) prasību neatkarīgiem elektroenerğijas ražotājiem noformulēšana. Rakstā apskatīti arī brīvā elektroenerğijas tirgus galvenie aspekti, funkcijas un uzdevumi, un elektrisko tīklu attīstības optimizācija kā elektroenerǵetisko sistēmu ilgtspējas vadības būtiska sastāvdaļa.

14.08.2008. 